\title{
Analysis of Zakat Management Performance and It's Implications Achievements of Sustainable Development Goals
}

\section{Naning Fatmawatie*}

Faculty of Islamic Economics and Business

IAIN Kediri, Indonesia naningfat@iainkediri.ac.id

\section{Nilna Fauza}

Faculty of Islamic Economics and Business

IAIN Kediri, Indonesia

\section{Elma Nur Rohmah}

Faculty of Islamic Economics and Business

IAIN Kediri, Indonesia

\begin{abstract}
The National Zakat Index is a measure of performance in zakat management. With good zakat management performance, it is expected to support the implementation of sustainable development goals (SDGs). The purpose of the study was to analyze the performance of zakat management in the City of Kediri BAZNAS based on the IZN approach and analyze its implications for SDGs' achievement. This research uses a mixed-methods approach. Nonstatistical quantitative methods and non-parametric qualitative methods. The results of this study in the 2019 value of IZN is not good. Macro dimension values with index are not acceptable. Besides, the database of zakat institutions is not good. Furthermore, the micro dimension, the performance of BAZNAS in Kediri City, is quite good. The influence of the performance of zakat management on the achievement of SDGs using the ANP method. Namely, the zakat program clusters occupy the priority of the Kediri program care, besides that the SDGs cluster is without poverty. The reason is the principle of zakat distribution in the City Board of Kediri prioritizing daruriyah (primary needs). Furthermore, the preferred strategy is cooperation with the government and stakeholders.
\end{abstract}

Keywords: Index, Zakat, National, Sustainable, Development, Goals

| Received October 2020 | Accepted December 2020 | Available online December 2020 |

| DOI: http://dx.doi.org 10.18860/mec-j.v4i3.10815

\section{INTRODUCTION}

Zakat management began from planning, implementing, and coordinating all activities in collecting, distributing, and utilizing zakat (Presidential Instruction No. 3 of 2014). Management of zakat according to RI Law Article 3 aims to improve the effectiveness and efficiency of services in zakat management; and increasing the benefits of zakat to realize community welfare and poverty reduction (Lubis, 2018).

Poverty has become an inseparable phenomenon from the reality of Indonesian people's lives. The problem of poverty can lead to the emergence of various economic, social, and other political problems, so the problem of poverty is a major concern of the Government of Indonesia (Armida, 2018). To measure poverty, BPS uses the concept of ability to meet basic needs (basic needs approach). With this approach, poverty is seen 
as an inability on the economic side to meet basic food and non-food needs as measured by expenditure. Here are the statistical data by the Central Statistics Agency on poverty in Kediri City:

Table 1. Number and Percentage of Poor People in Kediri City in 2012-2018

\begin{tabular}{cccccc}
\hline Year & $\begin{array}{c}\text { Number of } \\
\text { poor } \\
\text { population } \\
\text { (Po) }\end{array}$ & $\begin{array}{c}\text { Percentage } \\
\text { of poor } \\
\text { population } \\
(\%)\end{array}$ & $\begin{array}{c}\text { Depth } \\
\text { Index } \\
(\mathrm{P} 1)\end{array}$ & $\begin{array}{c}\text { Severity } \\
\text { Index } \\
(\mathrm{P} 2)\end{array}$ & $\begin{array}{c}\text { Poverty line } \\
\text { (Rp/capita/month) }\end{array}$ \\
\hline 2012 & 22300 & 8,11 & 0,82 & 0,14 & 316.693 \\
2013 & 22700 & 8,20 & 1,60 & 0,47 & 349.925 \\
2014 & 22130 & 7,95 & 0,91 & 0,17 & 366.788 \\
2015 & 23770 & 8,51 & 1,40 & 0,43 & 386.521 \\
2016 & 23640 & 8,40 & 0,96 & 0,20 & 400.096 \\
2017 & 24070 & 8,49 & 0,99 & 0,19 & 420.712 \\
2018 & 21900 & 7,68 & 0,87 & 0,18 & 453.807 \\
\hline
\end{tabular}

Based on the Central Statistics Agency, the number of poor people in Kediri City in 2014 was 22,130 people or around 7.95 percent of the population of Kediri City. The period from 2014-2015 has increased with the number of low population of 23,770 people or around 8.51 percent. Whereas in 2016, the number of poor people in the City of Kediri decreased slightly by 23,640 people or around 8.40 percent of the population in the City of Kediri. However, from 2016-2017 there was an increase in the number of poor people to 400 people. In 2018 the City of Kediri experienced a significant decrease in the number of poor people by 2,170 people. Based on these data, it can be concluded that the number of poor people in the City of Kediri has increased and decreased irregularly.

On the other hand, the problem of poverty is not only felt by the Indonesian people. In a broader setting, the world is also looking for common goals that have been agreed to be fulfilled by all countries, namely the Sustainable Development Goals (SDGs) (Amymie, 2017). To ensure the implementation of SDGs runs well, the government has formed the National Secretariat for Sustainable Development Goals (SDGs) (Shaikh, 2017). The SDGs National Secretariat is tasked with coordinating various activities related to implementing SDGs in Indonesia (Panuluh, 2016). Some stakeholders, including ministries/institutions, BPS, academics, experts, civil society organizations and philanthropy \& business, have been involved in various preparatory processes for implementing SDGs in Indonesia (Said et al., 2016). Islamic philanthropic institutions need to be formed as an effort to achieve SDGs, one of which is the zakat institution (Khalifah, 2017).

Zakat can serve as a source of social and economic funding for Muslims. Moreover, $85 \%$ of Indonesia's population is Muslim (BAZNAS, 2017). This indicates that the potential for collecting zakat funds in Indonesia is very large. Therefore, good management of zakat can help achieve Sustainable Development Goals. 
The National Zakat Index (IZN) has been established by the BAZNAS Strategic Study Center. The purpose of IZN is that all parties involved in zakat can measure themselves and improve their performance so that all zakat institutions can help the development of zakat in Indonesia (Widiawati, 2018). The National Zakat Index is divided into two dimensions, namely the macro dimension and the micro dimension (Diana, 2017). Macro dimensions include government regulations, government budget support for zakat, and databases of official zakat institutions, muzakki and mustahik. While the micro dimension includes institutions (collection, management, distribution, and reporting) and the impact of zakat using 3 analyzes, namely: CIBEST, Modification of the Human Development Index, and Independence (Beik, 2015).

The following data is the collection of ZIS funds at BAZNAS Kediri:

Table 2. Collection of BAZNAS in Residency of Kediri

\begin{tabular}{clr}
\hline No & \multicolumn{1}{c}{ Institution Name } & Collection Amount of ZIS \\
\hline 1 & BAZNAS Trenggalek & \pm Rp $3.000 .000 .000,00$ \\
2 & BAZNAS Blitar & Rp 970.000.000,00 \\
3 & BAZNAS Tulungagung & $>$ Rp 2.928.906.934,00 \\
4 & BAZNAS Nganjuk & Rp. $4.000 .000 .000,00$ \\
\hline
\end{tabular}

BAZNAS Kediri City has a report on receipt of Zakah infaq and alms (ZIS) funds in 20122018 as follows in Figure 1.

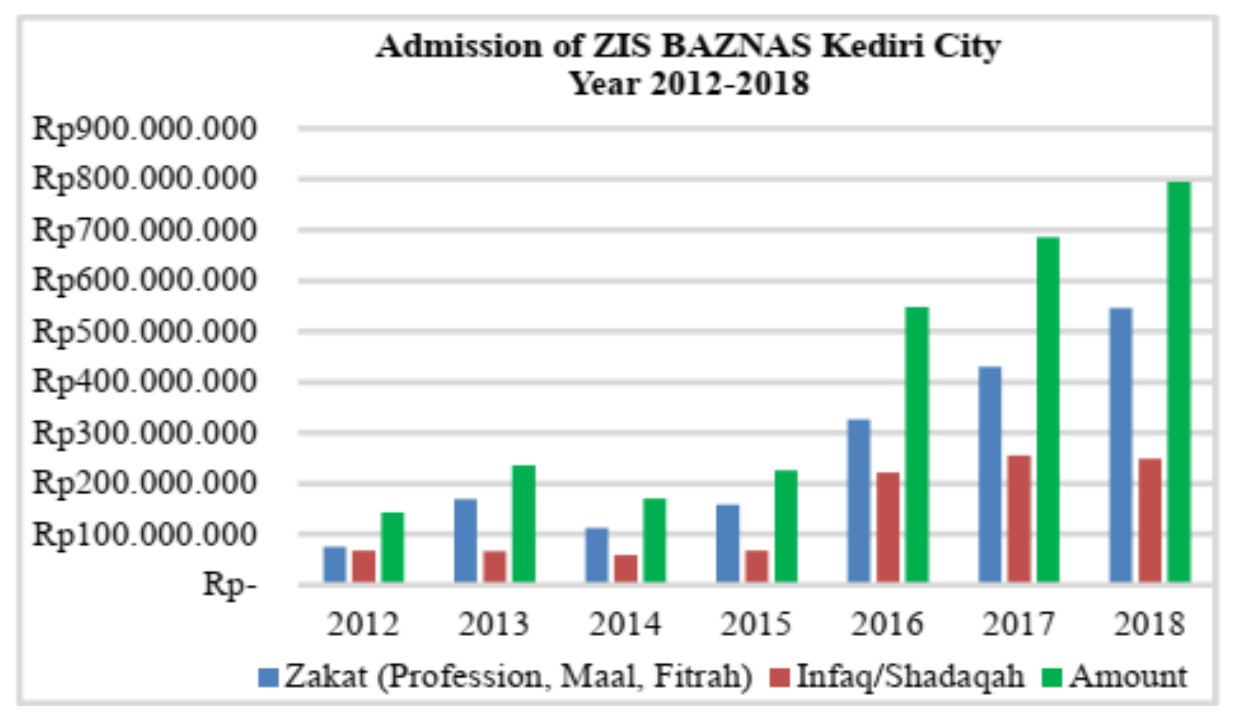

Figure 1. ZIS BAZNAS Acceptance Report Kediri City 2012-2018

Unlike the collection in the City of Kediri BAZNAS, which has increased, the distribution of zakat, infaq, and alms funds in the City of Kediri BAZNAS has not changed in the distribution system. 
Researchers are interested in examining the City of Kediri BAZNAS based on considering that the City of Kediri BAZNAS is the Amil Zakat Agency, which has the least amount of ZIS fund collection compared to the Amil Zakat Agency in other Cities / Regencies in the Kediri Secretariat. Based on the above data, it is essential to study zakat management's performance using the IZN approach and its implications for SDGs in the City of Kediri BAZNAS (Diana, 2017)

\section{THEORETICAL REVIEW}

\section{Zakat Management}

Zakat is understood as an obligatory practice for Muslims which is a solution to poverty alleviation. According to the term zakat is the giving of assets with a certain level to the rightful. Zakat is a pillar of Islam which has the benefit of empowering helpless individuals to become empowered. Zakat is an obligation for Muslims who have the ability to set aside a small portion of their assets for the benefit of those in need. Thus a professional and planned management is needed in distributing Zakat funds. There is an inoptimalism in the distribution of zakat funds, the unfortunate thing is that the recipients of zakat (muzakki) this year have not been motivated to become mustahik (zakat giver) in the coming year. In addition, the funds provided were only used for consumption. This then explains that zakat has not been able to reduce poverty optimally (Widiawati, 2018).

\section{The National Zakah Index (NZI) Approach}

To measure the performance of zakat management using the National Zakat Index (IZN) method. The National Zakat Index is divided into two dimensions, namely the macro dimension and the micro dimension(Panuluh, 2016). On the macro dimension, there are three viriables that are seen, namely regulation, government budget support, and a national database which includes official zakat institutions, mustahik and muzakki (Nugraha, 2017). Meanwhile, the micro dimension consists of institutional variables and the impact of zakat. "For institutions, it will be calculated starting from the collection, management, distribution and reporting of zakat. For the impact of zakat, there are three variables seen, namely material and spiritual, education and health, and independence (Said, 2016)

\section{Sustainable Development Goals (SDGs)}

The relationship between the management of zakat and the achievement of the SDGs is an idea where an approach that relies on the belief system / spirituality of the community will be accepted by the community with values and beliefs (Anindita, 2018). Actually Zakat can then become a source of funding in empowerment programs, but it doesn't stop at that. In zakat itself, there are values that can be developed that can answer the process of achieving the SDGs targets (Armida, 2018). The SDGs themselves always emphasize partnership and collaboration in alleviating poverty problems. At this time several Amil Zakat institutions have conducted community empowerment with the scope of each region(Beik, 2016). 


\section{METHODOLOGY}

This research method uses a combination of research methods (Tanzeh, 2016). The population in this study were all receipts of Zakat, infaq and Sadaqah (ZISWAF) BAZNAS in Kediri. While the sample is SZISWAF acceptance from 2012 to 2018. The sample was obtained by purposive sampling method. The variables of this research are zakat management, NZI method and SDGS. Data analysis technique use two analyzes, namely the calculation of the National Zakat Index (IZN) using non-statistical quantitative methods and the Analytic Network Process (ANP) and the implications of zakat management towards achieving Sustainable Development Goals (SDGs) using nonparametric qualitative methods (Teddie, 2010).

\section{RESULTS AND DISCUSSION}

\section{BAZNAS Performance in Kediri City Based on IZN}

The macro dimension illustrates the role of government and society, which contributes to building zakat institutions. This dimension consists of 3 indicators, namely regulation, APBD support, and the existing database: the number of official zakat institutions, the ratio of individual muzakki, and the ratio of muzakki of business entities. Based on calculations, the index value of the resulting macro dimensions is 0.165 . That is, the Kediri City government's performance in providing regulations, APBD support, and community contributions in building zakat institutions is not good. The following is an assessment of the performance of each variable in the macro dimension:

\section{Regulatory Indicators}

Because this research is at the city level, the absence of zakat management regulations gives a score of regulatory values equal to 1 (one) to get a zero index value. The performance of the City Government of Kediri related to the existence of zakat regulations is not very good, so the regulation provides powerful support for zakat development in the City of Kediri.

\section{APBD Support Indicators}

Based on calculations, the ratio of APBD to BAZNAS operational costs is $0.013 \%$, where the ratio obtained is less than $20 \%$. Then, the score obtained on the APBD support indicator is 1 (one), and the resulting index value is zero. This means that the performance of the City Government of Kediri is related to the APBD's support for BAZNAS operational costs, so that the existence of these costs is very weak for the sustainability of the City of Kediri BAZNAS.

\section{Database Indicators}

Based on calculations, it was found that the index value of the zakat institution database indicator was 0.165 . The performance of the City of BAZNAS Kediri in carrying out its duties and functions related to the zakat institution database is not good. The 
performance evaluation of each variable in this indicator is as follows: (a). Database variables of zakat, muzakki, and mustahik institutions. Based on the results of the study, the City of Kediri BAZNAS only has a list of official zakat institutions in the City of Kediri. The City of Kediri BAZNAS does not have a database of the number of mustahik and muzakki of each zakat institution. However, BAZNAS Kediri City only has data on the number of mustahik and muzakki based on the determination of the BAZNAS itself. Therefore, the score for this variable is 2 (two) and the resulting index value is 0.25 . (b). Individual muzakki database variables. It is known that the number of households in the City of Kediri is 74,612 and the number of individuals registered at the City of Kediri BAZNAS is 21 people with information that each registered individual has an NPWZ online. However, the City of Kediri BAZNAS has not issued an NPWZ card. Based on calculations, the ratio of the number of muzakki to households in Kediri is $0.028 \%$. This indicates that the ratio of individual muzakki is less than $1 \%$. Then, the score for this variable is 1 (one), and the resulting index value is zero. (c). Business entity muzakki database variable. The number of institutions in Kediri City is 10,431 institutional units consisting of business institutions, government agencies, and educational institutions. Whereas there are 112 units of registered institutions in the City of BAZNAS Kediri with information that every business entity registered in the City of Kediri BAZNAS already has an NPWZ online, but BAZNAS itself has not issued an NPWZ card. As calculated, the number of business entities' ratio to the number of business entities in the City of Kediri is $1.07 \%$. This indicates that the ratio of business entities in the range of $1-1.9 \%$. The score for this variable is 2 (two), and the resulting index value is 0.25 .

The micro dimension illustrates the performance of zakat institutions and the impact of zakat on mustahik(Wirawan, 2009). Based on the calculations performed, the resulting micro dimensional index value is 0.51 . That is, the performance of the City of BAZNAS Kediri in carrying out the institutional task of zakat is quite good. The existence of zakat also has a pretty good impact on mustahik. The following is an assessment of the performance of each variable on the micro dimension:

\section{Institutional Indicators}

The results showed that the index of institutional indicators obtained was 0.55 . This means that the City of BAZNAS in Kediri is quite good in carrying out its tasks and functions related to institutional activities, including collection, management, distribution, and reporting. (a). Collection Variable; Based on the financial statements of the City of BAZNAS Kediri, it was calculated that the growth rate of ZIS collection in 2018-2019 was 3.97\%. This indicates that the growth of the ZIS collection is less than $5 \%$ Then, the score obtained on this variable is 1 (one), and the resulting index value is zero. (b). Management Variables; The results showed that the City of Kediri BAZNAS has SOP (Standard Operating Procedures) including the SOP of distribution and utilization of ZIS, amil correspondence and education, and the City of Kediri City has an annual program and strategic planning in the form of socialization in agencies, print media, banners, banners, pamphlets, and calendars. However, at BAZNAS, the City of Kediri does not yet have ISO certification / quality management (Elbadiansyah, 2019). This causes the management variable to get a score of 4 and the resulting index value is 0.75 . (c). 
Channeling Variable; The results showed that the City of Kediri BAZNAS that the City of Kediri BAZNAS had 5 ZIS funds distribution programs, namely smart Kediri, caring Kediri, healthy Kediri, pious Kediri, prosperous Kediri. Of the five programs, there is a product distribution in the form of a revolving fund in the successful Kediri program and consumption distribution in other social programs. The realization is between January and December, and there is no specific amount of funding for that program. However, BAZNAS Kediri City does not provide allocation funds for the da'wah program. Based on the calculation results, it was found that the ACR value was $77.59 \%$. Then, the average score for the distribution variable is 4 (four) and the resulting index value is 0.75 . (d). Reporting Variable; Based on the study results, Kediri City BAZNAS has published financial reports, audited by the internal management of Kediri City BAZNAS, unaudited, and did not get a WTP (Fair Without Exception) opinion from the Supreme Audit Board (BPK). Then, the variable distribution score is 3 (three), and the resulting index value is 0.50 .

\section{Zakat Impact Indicator}

Zakat impact indicators consist of CIBEST welfare variables, HDI modification variables, and independent variables. These three variables are measurement tools to determine the impact of zakat on the aspects of mustahik life. The results showed that the zakat impact indicator index obtained 0.50 . This value indicates that the performance of the City of BAZNAS in Kediri is quite good in helping the welfare of the mustahik life from the spiritual, material, educational, health and independence aspects. (a). CIBEST Welfare Index Variable; The analysis results above show that the welfare index value $(w)$ of mustahik households is 0.46 . In this case, the index value is in the index range of 0.41$0.60 \%$. Then the score for the CIBEST welfare variable is 3 (three), and the resulting index value is 0.50. (b). HDI Modification Variable; Because the HDI component modification index is 0.45 , it means the health and education index of BAZNAS Kediri City reaches 45 percent. Then, the value of HDI's variable modification obtained a score of 3 whose value is in the range of 0.41 to 0.60 , which is 0.45 . (c). Independence Variable; The score obtained on the independent variable is 3 (three), and the resulting index value is 0.50 .

Based on the results of calculations that have been done, it is known that the macro dimension index obtained is 0.165 . This means that government support and community contributions from Kediri City are not good (Beik, 2015). While calculating the micro dimension index, it is known that the value obtained is 0.51 . This value shows that the institutional performance and the impact of zakat on the life of mustahik are considered quite good.

Based on the calculation of the macro and micro dimension index, it is known that the value of IZN BAZNAS of Kediri City is 0.372 and is in the range of values $0.21-0.40$. This shows that the performance of zakat in the City of Kediri BAZNAS in 2019 is not good (Yunus, 2019). 
Implications of Zakat Management in the City of Kediri BAZNAS on Achieving Sustainable Development Goals

\section{BAZNAS City Cluster Program in Kediri}

Based on the results of the geometric mean in the BAZNAS cluster program with the first order results ie Kediri cares about the value of 0.0136 . The second sequence is Kediri Taqwa with a value of 0.0126 , the third program sequence is Kediri Smart with a value of 0.012254 , the fourth program is Kediri Prosperous with a value of 0.012017 and finally the healthy Kediri with a value of 0.012681 . The Kediri Care Program is a program with top priority, Kediri cares about the distribution which is consumptive for the poor. This is in accordance with the policy of the City of Kediri BAZNAS, which prioritizes the consumptive first because the consumptive is more urgent (Khalifah, 2017).

\section{Sustainable Development Goals Cluster}

Priority geometric mean results in the SDGs cluster, including: first, without poverty (0.00873), without hunger (0.00863), quality education (0.00855), decent work (0.00752), peace justice and resilient institutions (0.00752), cities \& sustainable settlements (0.00752) 0.0073), good health (0.00708), and reduced gaps (0.00706). Based on these results it can be seen that values with high priority are without poverty, without hunger, and quality education. While other points have almost the same value at 0.007 .

\section{Kediri City Strategy BAZNAS Strategy Cluster to Help Achieve SDGs}

Based on literature and inept interview, the Analytic Network Process (ANP) cluster strategy method consists of 5 strategy nodes. The results of the geometric mean in the strategy cluster are socialization of the community to the community (0.01331), collaboration with the government and stakeholders (0.0139), increasing human resources (0.0119), optimizing the application of zakat (0.01175), innovating the collection and distribution system of zakat (0.01152). These results can illustrate the strategic priorities undertaken by the City of BAZNAS in Kediri to help the achievement of SDGs.

The main priority is cooperation with the government and stakeholders, the cooperation in question can be in the form of collecting and channeling zakat funds. The second strategy priority is the dissemination of zakat to the public. The size of the distribution of zakat funds depends on the collection of zakat, therefore the socialization of zakat is very necessary for the people of Kediri City. Based on the financial statements of the City of Kediri BAZNAS in September 2019 there was also an awareness of zakat awareness activities (Lubis, 2019). Other strategies have almost the same value, including: increasing human resources (0.0119), optimizing the application of zakat (0.01175), innovating the collection system and distributing zakat (0.01152). Increasing HR management of BAZNAS becomes the third priority, because this is important for the continuation of zakat in Kediri City. 
Innovation in the collection and distribution system of zakat occupies the last priority. Explanation of the above strategy is mostly about the collection system, because the management of zakat can have a good impact and impact on the achievement of SDGs is the distribution of zakat funds, distribution of zakat funds can be optimized along with the optimal collection of zakat funds so that the optimization of the zakat collection system is very optimal. It is necessary to innovate the zakat fund distribution system so that it is right on target, both zakat distribution by the administrators of BAZNAS City of Kediri and UPZ (Shaikh, 2017).

\section{CONCLUSION}

The performance of BAZNAS of Kediri City in 2019 was not good. Because the value of the National Zakat Index obtained by 0.372 . Based on the macro dimension obtaining an index of 0.165 , the role of government and community contribution to the development of zakat in Kediri City is not good because the regulation on zakat management is revoked, APBD support is less than 20\%, and the database of zakat institutions is not good. Based on the micro dimension, the performance of the City of BAZNAS in Kediri is quite good with an index of 0.51 , this value indicates that the institutional performance and the impact of zakat on the life of mustahik is considered quite good.

Based on the management of zakat on the achievement of SDGs using the ANP method. In the zakat program cluster, the priority is Kediri caring, and the SDGs cluster is without poverty. This is because the principle of the distribution of zakat in the City of Kediri BAZNAS prioritizes daruriyah (primary needs), which is well implanted and implemented. At the same time, the most prioritized strategy is a collaboration with the government and stakeholders.

\section{REFERENCES}

Amymie, F. (2017). Optimalisasi Pendistribusian dan Pendayagunaan Dana Zakat dalam Pelaksanaan Tujuan Program Pembangunan Berkelanjutan (SDGs). ANIDA, 17(1i).

Anindita, S. F. dan S. S. (2018). Analisis Potensi Zakat dalam Pencapaian Program SDGs di 34 Propinsi di Indonesia. 6 Th Southeast Asia International Islamic Philanthropy Conference.

Armida. (2018). Tujuan Pembangunan Berkelanjutan di Indonesia: Konsep, Target dan Strategi Implementasi. Bandung: UNPAD Press.

BAZNAS, D. R. dan P. K. S. (2017). Outlock Zakat Indonesia. Pusat Kajian Strategis BAZNAS.

Beik, I. S. (2015). Consctuction Of Cibest Model As Measurement Of Proverty And Welfare Indices From Islamic Perspective. Al-Iqtishad, VII(1).

Beik, I. S. (2016). Islamisasi IImu Ekonomi. Jurnal Ekonomi Islam Center of Islamic Business and Economic Studies, 7(2), 77.

Diana, D. (2017). Performance Analysis Of Zakat Practices In East Lampung Regency Using National Zakat Index. In PUSKAS. 
Elbadiansyah. (2019). Manajemen Sumber Daya Manusia. Malang: Cv. Irdh.

Khalifah, M. H. (2017). Optimization Of Baznas Programs On Sustainable Development Goals (SDGs): Analytic Network Process Approach (ANP). International Journal of Zakat, 2(2).

Lubis, R. H. dan F. N. L. (2019). Analisis Strategi Pengembangan Zakat, Infaq, Sadaqah dan Wakaf di Indonesia (Analysis Of Zakat, Infaq, Sadaqah and Wakaf Development Strategies In Indonesia). Perisai: Islamic Banking and Finance Journal, 3(1).

Nugraha, F. (2017). Kontribusi Lembaga Zakat terhadap Pencapaian Sustainable Development Goals (SDGs). Program Development Departement Head Rumah Zakat.

Panuluh, S. (2016). Perkembangan Pelaksanaan Sustainable Development Goals (SDGs) di Indonesia. Infid.

Peraturan Pemerintah Republik Indonesia Nomor 14 Tahun 2014 Tahun 2014 tentang Pelaksanaan Undang-Undang Nomor 23 Tahun 2011 tentang Pengelolaan zakat Pasal 1 ayat 1.

Said, Ali, D. (2016). Tujuan Pembangunan Berkelanjutan (Sustainable Development Goals) di Indonesia. Badan Pusat Statistik Indonesia.

Shaikh, G. A. (2017). Role Of Zakat in Sustainable Development Goals. International Journal Of Zakat, 2(2).

Tanzeh, A. (2016). Metodologi Penelitian Praktis. Yogyakarta: Teras.

Teddie, T. dan. (2010). Handbook of Mixed Methods in Social \& Behavioral Research. Yogyakarta: Pustaka Pelajar.

Widiawati. (2018). Kinerja Pengeloaan Zakat Menggunakan Indeks Zakat Nasional (IZN) di BAZNAS Propoinsi Jawa Barat. Proseding Keuangan Dan Perbankan Syariah, 4(1).

Wirawan. (2009). Evaluasi Kinerja Sumber Daya Manusia. Jakarta: Salemba Empat.

Yunus, A. R. dan N. F. (2019). Kinerja Badan Amil Zakat Nasional Provinsi Sulawesi Selatan (Tinjauan Makrfo). ASSETS, 9(1). 